\title{
Motivasi dan Persepsi Penonton Hellprint United Day 2018 di Bandung
}

\author{
Yayat Ahmad Hidayat \\ Program Pascasarjana Institut Seni Indonesia Yogyakarta \\ kybohemian@gmail.com
}

\begin{abstract}
Abstrak
Hellprint United Day adalah event festival musik metal tahunan yang rutin diselenggarakan oleh Hellprint Official dan Supermusic.id di Bandung. Munculnya ide untuk menyelenggarakan event ini dikarenakan banyaknya penggemar musik metal di Kota Bandung, termasuk adanya komunitas metal underground. Menurut data dari Hellprint Official bahwa pada penyelenggaraan Hellprint 2013 penyelenggara mampu menjual tiket terhadap 38.000 penonton dan itu merupakan penonton terbanyak sepanjang sejarah penyelenggaraan Hellprint. Jika ditinjau dari perspektif bisnis, jumlah tersebut mengindikasikan adanya potensi ekonomi pada industri musik metal di Bandung di bidang pertunjukan. Akan tetapi menurut Hellprint Official pula bahwa pada beberapa penyelenggaraan berikutnya terjadi penurunan jumlah penonton yang faktor penyebabnya belum diketahui secara pasti. Untuk menangani masalah ini pada penyelenggaraan Hellprint United Day VI tahun 2018, penyelenggara melakukan beberapa inovasi pada beberapa faktor, di antaranya desain panggung, venue pertunjukan, fasilitas penonton, dan line up artis. Inovasi dilakukan untuk menjaga motivasi dan persepsi positif penonton demi keberlangsungan event. Peneliti telah melakukan penelitian kualitatif terhadap penonton Hellprint United Day VI 2018 melalui metode studi kasus. Artikel ini ditulis untuk menjelaskan motivasi dan persepsi penonton sehingga menjadi masukan bagi penyelenggaraan berikutnya. Hasil penelitian menunjukkan bahwa silaturahmi adalah motivasi utama penonton. Sedangkan desain dan artistik panggung adalah hal yang dipersepsikan positif oleh mayoritas penonton.
\end{abstract}

Kata kunci: motivasi, persepsi, musik metal, hellprint, supermusic.id.

\begin{abstract}
Hellprint United Day is an annual metal music festival event that is regularly held by the Official Hellprint and Supermusic.id in Bandung. The idea of holding this event was due to the many metal music fans in Bandung, including the underground metal community. According to data from the Hellprint Official that the holding of Hellprint 2013 organizers were able to sell tickets to 38,000 spectators and that was the largest audience in the history of Hellprint. If viewed from a business perspective, this number indicates the economic potential of the metal music industry in Bandung in the field of performances. However, according to the Hellprint Official, there are also a decrease in the number of spectators whose exact causes are unknown. To deal with this problem in the holding of Hellprint United Day VI in 2018 the organizers made several innovations on several factors, including stage design, venue performances, audience facilities, and artist line ups. Innovation is done to maintain motivation and audience positive perceptions for the continuity of the event. The researcher has conducted qualitative research on the Hellprint United Day VI 2018 audiences through a case study method. This article was written to explain the motivation and perceptions of the audience so that it became an input for the next implementation. The results of the study show that
\end{abstract}


friendship is the main motivation of the audience. While the design and artistic stage are things that are positively perceived by the majority of the audiences.

Keywords: motivation, perception, metal music, hellprint, supermusic.id.

\section{PENDAHULUAN}

Musik heavy metal yang selanjutnya disebut dengan metal terlahir dari Birmingham Inggris pada ahir tahun 1960-an dan awal 1970-an. Secara musikal kelahiran jenis musik ini merupakan pengembangan dari musik hard rock yang sudah dikembangkan terlebih dahulu oleh grup Deep Purple. Sedangkan secara sosiologis lahirnya musik ini berbarengan dengan munculnya fenomena kenaikan pengangguran, inflasi, dan pemogokan buruh. Black Sabbath adalah band Birmingham yang merupakan pelopor musik metal pertama di dunia. Musik mereka mampu merefleksikan anti kemapanan yang mampu merangkul pelarian, fantasi, dan menginspirasi anak-anak muda yang kehilangan haknya (Cope, 2010, hal. 97).

Musik metal Inggris pada ahirnya menyebar ke berbagai belahan dunia termasuk ke Indonesia. Pengaruh yang paling besar pada perkembangan musik metal di Indonesia terasa setelah Sepultura (1992) dan Metallica (1993) mengadakan konser di Jakarta yang menginspirasi tumbuhnya para metal head (penggemar musik metal) dan komunitas penggemar musik metal di Jakarta, Bandung, dan kota-kota lainnya. Termasuk munculnya festival musik metal di Jakarta, Bandung, Yogyakarta, dan Denpasar yang diselenggarakan oleh masing-masing komunitas. Sebagai musik ekstrim yang disukai minoritas orang, fundrising festival metal tidak didukung sponsor seperti pada jenis musik populer lainnya tetapi melalui dana sumbangan dari sesama metal head.

Bandung sebagai kota yang banyak dihuni para metal head adalah daerah yang sering mengadakan festival musik metal selain Jakarta. Penyelenggaraan event tersebut didanai secara swadaya oleh para penggemar yang tergabung dalam komunitas metal underground Bandung. Festival musik metal yang tergolong besar dan berskala internasional adalah "Bandung Berisik" dan "Hellprint United Day" yang selalu dihadiri oleh ribuan metal head dari Bandung dan berbagai kota di Indonesia.

Hellprint Officials adalah sebuah event organizer berbadan hukum yang berkedudukan di Bandung. Kehadiran mereka telah memberikan dampak pada regenerasi musisi metal dan metal head di Bandung. Upaya yang dilakukan untuk kontinuitas musik metal dilakukan dengan cara mengadakan kompetisi band metal di Jawa Barat. Selanjutnya band-band yang lolos kompetisi ditampilkan pada Hellprint United Day sebagai event tahunan mereka.

Kegiatan kompetisi ini mulai dilakukan sejak tahun 2010 sebagai rangkaian kegiatan penyelenggaraan Hellprint United Day 2011 dan masih berlangsung hingga sekarang. Untuk penyelenggaraan Hellprint United Day 2011 dan 2012 seluruh pembiayaan ditanggung oleh Dany Kajul sebagai pemilik Hellprint Officials. Sedangkan pada penyelenggaraan Hellprint United Day III yang diselenggarakan tanggal 8 September 2013 Hellprint Officials mulai bekerja sama dengan supermusic.id sebagai sponsor. Kerja sama tersebut mampu meningkatkan skala pertunjukan, termasuk adanya 
peningkatan jumlah penonton yang hadir hingga mencapai 38.000 orang. Akan tetapi menurut penyelenggara telah terjadi penurunan jumlah total penonton pada tiga tahun terakhir. Penurunan tersebut berdampak pada turunnya profit dan benefit yang diterima pihak penyelenggara, termasuk beban tanggung jawab terhadap supermusic.id sebagai sponsor. Walaupun angka penurunan masih di atas target minimal (10.000 penonton) yang ditentukan, tetapi sebagai sebuah organisasi profesional mereka dituntut cepat tanggap terhadap fenomena yang terjadi. Untuk menghadapi masalah ini Hellprint Officials melakukan upaya dengan memutakhirkan konsep pertunjukan melalui inovasi pada desain panggung, venue pertunjukan, jenis band, dan genre musik yang ditampilkan, serta mengubah beberapa fasilitas dan hospitality untuk penonton pada Hellprint United Day VI.

Upaya seperti ini sangat baik bagi keberlangsungan event, akan tetapi belum tentu mampu menjawab harapan penonton. Terlebih jika merujuk pada fenomena awal bahwa festival musik metal underground di Bandung digelar atas inisiasi komunitas. Secara umum (common sense) event metal underground lebih banyak difungsikan sebagai media untuk bersosialisasi (silaturahmi) antar-anggota komunitas dan hal ini pun dibenarkan oleh Hellprint Official. Dengan kata lain bahwa kehadiran penonton lebih didasari pada motivasi untuk bersilaturahmi di antara anggota komunitas, selain untuk kepentingan hiburan, apresiasi, dan yang lainnya. Dengan keadaan seperti ini memunculkan asumsi bahwa penyusutan penonton diakibatkan Hellprint United Day tidak dapat dijadikan sebagai media silaturahmi yang merupakan motivasi utama para metal head. Sedangkan asumsi lainnya karena terdapat motivasi lain dari penonton yang tidak terakomodir oleh penyelenggara. Asumsi tersebut perlu dibuktikan mengingat motivasi penonton yang datang ke venue secara natural akan berbeda-beda. Selain itu, setelah mereka hadir, hospitality atau treatment apa yang akan diberikan oleh penyelenggara kepada penonton agar harapan mereka terpenuhi. Terkait dengan treatment tersebut penulis belum menemukan literatur studi yang valid tentang hal-hal apa saja yang harus diberikan oleh penyelenggara terhadap para penonton musik metal.

Akan tetapi jika merujuk pada beberapa pendapat yang berhubungan dengan prinsip penyelenggaraan event secara umum bahwa penyelenggaraan event dipicu karena adanya kebutuhan manusia terhadap saat-saat atau momen istimewa yang mampu memberikan pengalaman-pengalaman baru yang menyenangkan dan mengesankan. Saatsaat istimewa tersebut diperoleh pada saat menghadiri acara-acara atau seremonial yang bersifat eksklusif. Dalam hal ini termasuk pula mendatangi acara-acara yang mampu menggugah perasaan gembira dan mampu memberikan pengalaman spesifik dalam hidupnya (AJ Bowdin et al., 2006; Wrathall dan Gee, 2011, hal. 11).

Dalam konteks pertunjukan musik, pengalaman yang disampaikan harus memiliki standar tinggi (Donald Getz, 2007, hal. 192). Sedangkan pengalaman tinggi itu sendiri dapat terjadi ketika sebuah organisasi (kepanitiaan) secara sengaja menggunakan layanan sebagai pentas, dan infrastruktur sebagai alat peraga untuk melibatkan individu dengan cara yang dapat menciptakan pengalaman yang tak terlupakan (Pine dan Gilmore, 1998, hal. 98).

Dengan mengacu pada beberapa literatur tersebut, memunculkan asumsi lanjutan bahwa harapan penonton akan terpenuhi apabila motivasi mereka difasilitasi sedemikian 
rupa melalui pemberian pengalaman-pengalaman yang menyenangkan, spesifik, dan berstandar tinggi. Sehingga menghadiri event akan dipersepsikan sebagai sebuah aktivitas yang memberikan pengalaman yang tak terlupakan. Asumsi seperti ini perlu dibuktikan mengingat preferensi kesenangan, pengalaman tinggi, dan pengalaman tak terlupakan bagi tiap individu akan berbeda-beda. Sebuah aktivitas yang ditawarkan penyelenggara mungkin akan dipersepsikan sebagai sesuatu yang sangat menyenangkan oleh satu individu. Akan tetapi oleh individu lainnya mungkin dianggap sebagai sesuatu yang biasa atau malah tidak menyenangkan sama sekali. Demikian pula dengan pengalaman tinggi dan pengalaman tak terlupakan yang ditawarkan penyelenggara.

Upaya untuk menghadapi turunnya populasi penonton memang telah dilakukan Hellprint Official melalui inovasi desain panggung, venue pertunjukan, band, dan jenis musik yang ditampilkan, serta mengubah beberapa fasilitas. Jika ditinjau dari teori klasik Theodore M. Newcomb (1958), inovasi tersebut sudah tergolong pada upaya mengarahkan tingkah laku penonton untuk mencapai tujuan. Akan tetapi inovasi yang dilakukan seharusnya diasumsikan sebagai sebuah akibat dari sebab adanya motif dan persepsi tertentu yang muncul pada diri penonton. Sementara di sisi lain, keragaman motivasi dan persepsi penonton memang tidak akan bisa diakomodasikan sepenuhnya pada suatu inovasi, akan tetapi populasi penonton yang mayoritas berasal dari komunitas dengan karakter loyal dapat dipertimbangkan. Penonton dapat dianggap sebagai sebuah populasi homogen dan penggemar musik metal yang satu akan menganggap penggemar musik metal lainnya sebagai satu entitas.

Berdasar pada pemikiran tersebut, studi kualitatif terhadap motif dan persepsi yang muncul pada individu penonton perlu dilakukan. Studi tersebut adalah untuk membuktikan berbagai asumsi yang muncul dan berkembang sehingga fenomena permasalahan menjadi jelas. Untuk kepentingan ini penulis telah melakukan studi terhadap penyelenggaraan Hellprint United Day VI pada tanggal 4 Februari 2018, di Lapangan Pussenif, Jl. Supratman Bandung. Hasil penelitian tersebut dituangkan pada artikel ini dengan maksud untuk dijadikan sebagai salah satu literatur yang mampu memberikan informasi dan rujukan secara logis dan faktual kepada penyelenggara. Tujuannya adalah untuk dijadikan masukan bagi Hellprint Official sebagai penyelenggara saat mengambil solusi terhadap permasalahan yang sedang dihadapi. Selain itu artikel ini juga diharapkan menjadi salah satu sumbangan pemikiran untuk memperkaya khazanah disiplin tata kelola seni pertunjukan.

\section{Motivasi Penonton}

Menurut kamus bahasa yang diterjemahkan secara bebas, motivasi diartikan sebagai antusiasme atau kondisi yang mendorong seseorang yang disertai dengan alasan kuat, atau secara sadar dan tidak sadar untuk bertindak atau berperilaku dengan cara tertentu. Motivasi biasanya mengacu pada perilaku tindakan sukarela yang menunjukkan arah (Forgas et al, 2005; Global Journal of Human Social Science). Faktor motivasi seseorang dapat dibedakan dalam tiga faktor: Kecenderungan dan kebutuhan perilaku universal, Motif disposisi (motif implisit) yang membedakan antara individu, Sasaran (motif eksplisit) yang diadopsi dan dikejar individu (J. Heckhausen dan H. Heckhausen, 2018, hal. 4). Penonton metal, seperti semua penonton modern yang tersebar secara 
spasial, memiliki "kekhususan, kegigihan/keteguhan, dan apa adanya", tetapi "menutup diri saat melihat banyak perbedaan" (Weinstein, 2000, hal. 95). Sedangkan musik metal itu sendiri bagi mereka akan terkait dengan cara hidup, yang memberikan rasa memiliki dan makna (Phillips \& Cogan, 2009, hal. 6). Dengan demikian penonton yang datang pada acara festival metal cenderung memiliki selera dan nilai-nilai sosial yang sama. Akan tetapi ketika mereka hadir ke venue belum tentu memiliki motif yang sama. Bahkan Kruger dan Saayman (2012, hal. 199) menyatakan bahwa motif tidak hanya berbeda dari genre ke genre, tetapi juga akan berbeda dari satu tempat ke tempat lainnya. Hal ini menyiratkan bahwa hasil penelitian tentang motivasi penonton di satu wilayah tidak dapat diterapkan ke wilayah lainnya.

\section{Persepsi Penonton}

Terdapat beberapa literatur tentang pengertian persepsi yang penulis temukan, namun secara umum memiliki makna yang sama. Persepsi dihubungkan dengan tindakan interpretasi seseorang berdasarkan sudut pandang masing-masing terhadap stimulus yang diterima inderanya. Robinson (2003, hal. 6) memaparkan sebagai proses fisik yang melibatkan organ pancaindra yang menghasilkan kesan atau fantasi yang -kurang lebihbersifat fisikal (konkrit). Hingga akhirnya dia meringkasnya sebagai penerimaan bentuk suatu objek tanpa materi. Sedangkan Bernstein et.al. (2008, hal. 153) mendefinisikan persepsi sebagai proses yang melalui sensasi ditafsirkan, menggunakan pengetahuan dan pemahaman, sehingga menjadi pengalaman yang bermakna. Sementara penafsiran lainnya yang penulis kutip dari sebuah situs internet mendefinisikan persepsi sebagai "pengakuan dan interpretasi kita terhadap informasi sensorik. Persepsi juga mencakup cara kita merespons informasi. Kita dapat menganggap persepsi sebagai suatu proses di mana kita mengambil informasi indrawi dari lingkungan kita dan menggunakan informasi itu untuk berinteraksi dengan lingkungan kita" (https://study.com//academy).

Persepsi penonton saat berada di venue umumnya akan terbagi dua yaitu persepsi visual dan auditori. Proses persepsi visual penonton berhubungan dengan sensasi dan rangsangan yang mereka lihat dan akan melibatkan penggunaan pengetahuan yang diperoleh dari pengalaman dengan dunia visual. Bersama dengan proses perhatian dan memori, pemrosesan perseptual memunculkan pengalaman terhadap objek dan peristiwa visual di sekitar (Styles, 2005, hal. 49). Sedangkan persepsi auditori menurut Styles akan berhubungan dengan sensasi auditif yang mengandung unsur musikal (seperti: pitch, timbre, tempo, dinamika) dan nonmusikal dengan beragam tingkat kekerasan bunyi (loudness).

\section{Acara Spesial (Special Event)}

Jika menelusuri beberapa literatur dari beberapa ahli dan peneliti terdahulu, terdapat beberapa pengertian tentang acara spesial atau special event. Goldblatt menyebutkan sebagai sebuah momen unik dalam satu waktu tertentu yang di dalamnya terdapat selebrasi secara seremonial untuk kebutuhan kepuasan yang spesifik (Goldblatt, 2005, hal. 6; A.J. Bowdin, 2006, hal. 13). Donald Getz (2005), menyatakan sebagai kesempatan untuk suatu acara menyediakan berbagai pengalaman budaya, sosial, dan pengalaman santai yang melampaui pengalaman rutin sehari-hari, dan peristiwa inilah 
yang disebut special event. Definisi lainnya menyiratkan bahwa special event adalah peristiwa dalam satu waktu atau yang jarang terjadi pada umumnya suatu acara. Bagi pelanggan atau hadirin, special event merupakan suatu kesempatan untuk mendapatkan pengalaman rekreasi, sosial, atau budaya, di luar pengalaman normal sehari-hari (Donald Getz, 2005, hal. 16; A.J. Bowdin, 2006, hal. 13). Sementara untuk mengesankan special event, Troy Halsey (2010, hal. 44-59) lebih menyarankan penataan dan penggunaan infrastruktur yang tidak normal/istimewa pada tata panggung (staging) dan infrastruktur lainnya. Dengan demikian special event mencakup momen unik dalam satu waktu tertentu (Goldblatt, 2005) yang jarang terjadi pada acara umum atau sehari-hari (Getz, 2005) yang melibatkan individu sehingga mampu menciptakan pengalaman tak terlupakan (Pine dan Gilmore, 1998). Pengalaman pengunjung yang tak terlupakan tidak dapat dianggap homogen (Manners, 2012, hal. 20). Satu event akan dianggap sebagai sebuah pengalaman dan makna yang tinggi bagi satu individu, akan tetapi akan berlaku sebaliknya bagi individu yang lain, sehingga pengalaman yang diberikan akan dimaknai secara beragam oleh masing-masing penonton. Dengan demikian kita perlu mengetahui motif atau tujuan aktual penonton pada umumnya yang menghadiri suatu konser atau event.

Hasil studi kasus beberapa peneliti menginformasikan bahwa berbagai rangkaian acara seni telah mengeksplorasi pengalaman audience dan kelompok secara lebih kontekstual, mengeksplorasi faktor sosial, termasuk loyalitas penonton (Pitts \& Spencer, 2008), komunitas, rasa memiliki (Burland \& Pitts, 2010), dan efek performa dari interaksi pemain dengan penonton (Brand, Sloboda, Saul, \& Hathaway, 2012; Lamont, 2012). Selain itu, bagi para penggemar musik, konser lebih dari sekadar acara regular, melainkan pertemuan yang bermakna antar berbagai ide dan orang (Lobert, 2012).

Pada umumnya pertunjukan musik metal lebih sering menggunakan konsep festival di tempat terbuka (outdoor) daripada konser tunggal di tempat tertutup. Sebuah festival menyiratkan bahwa pengunjung cenderung mencari pengayaan budaya, pendidikan, kebaruan, dan sosialisasi (Crompton \& McKay, 1997). Dalam konteks konser musik sebagai event festival, Getz (1991) mengemukakan bahwa kebutuhan dasar yang dipenuhi oleh festival dapat dikelompokkan menjadi 'tiga kategori: fisik, interpersonal atau sosial, dan pribadi'. Sedangkan yang terkait dengan pengalaman diartikan sebagai hasil dari keterlibatan seseorang secara personal, dan karena itulah nilai (dari acara) akan bertahan lama setelah acara selesai dilaksanakan (Pine dan Gilmore, 1999, hal. 12-13).

\section{Inovasi}

Perencanaan adalah salah satu bagian dari kegiatan tata kelola, termasuk juga tata kelola pertunjukan musik. Pada pertunjukan yang belum pernah dilaksanakan, pihak pengelola perlu melakukan studi kelayakan secara menyeluruh untuk menentukan tingkat feasibility pertunjukan. Sedangkan untuk pertunjukan yang berulang (termasuk annual event) maka keputusan awal perlu dibuat. Perencanaan untuk pertunjukan berulang ditentukan berdasarkan pada data dan pengalaman yang lalu. Bowdin et al. (2006, hal. 119-120) menyatakan bahwa manajer acara sering menemukan diri mereka dalam situasi di mana mereka berencana untuk membuat acara yang berulang seperti festival tahunan 
atau pameran, sehingga keputusan awal saat perencanaan dipengaruhi pengalaman pribadi penyelenggara pada penyelenggaraan sebelumnya.

Pada event festival yang diselenggarakan secara berulang, pengulangan konsep event akan menjadikan pengalaman yang diterima oleh penonton menjadi rendah. Sedangkan pengalaman akan dipersepsikan secara positif apabila pengalaman yang disampaikan memiliki standar tinggi (Donald Getz, 2007). Maka dengan demikian, penyelenggara dituntut untuk berinovasi dengan cara membuat ide atau metode baru (https://dictionary.cambridge.org/dictionary/), termasuk melalui penataan dan penggunaan infrastruktur yang tidak normal/istimewa pada tata panggung (staging) dan infrastruktur lainnya (Troy Halsey, 2010).

\section{METODE}

Meneliti motivasi dan persepsi penonton pada sebuah pertunjukan sama artinya dengan menilai penonton secara subjektif karena akan berhubungan dengan sikap, perasaan (feeling), kesukaan, dan pendapat penonton. Penelitian di bidang ini membutuhkan pemahaman holistis, di mana wawasan dan keterlibatan penulis menjadi kunci utama saat melakukan penelitian. Jika merujuk pada beberapa literature, ditemukan kesamaan bahwa tema penelitian seperti ini adalah ranah dari paradigma kualitatif.

Pendekatan kualitatif akan memberikan hasil yang baik dalam bentuk nonkuantitatif atau dalam bentuk yang tidak mengalami analisis kuantitatif yang ketat dan umumnya teknik wawancara kelompok fokus, teknik proyektif, dan wawancara mendalam digunakan (Kothari, 2004, hal. 5). Sedangkan dalam menentukan ukuran sampel, penulis merujuk pada konsep klasik Glaser dan Strauss (1967). Jumlah sampel pada penelitian kualitatif akan dinyatakan cukup apabila dari sampel yang diambil tidak lagi menghasilkan perspektif atau informasi tambahan (jenuh). Atas dasar rujukan Glasser dan Strauss tersebut kegiatan wawancara dari satu narasumber ke narasumber lainnya dihentikan pada saat informasi yang diperoleh telah mencapai saturasi data (jenuh).

Metode yang dipergunakan pada penelitian ini adalah studi kasus, mengingat pertunjukan musik bersifat temporer yang dibatasi oleh waktu, sehingga penelitian ini memiliki kerangka waktu yang ditentukan (Leedy \& Ormrod, 2001, hal. 149). Studi kasus adalah bentuk analisis kualitatif yang melibatkan pengamatan unit sosial yang cermat dan lengkap, baik itu unit seseorang, keluarga, lembaga, kelompok budaya, atau bahkan seluruh masyarakat. Metode penelitian ini lebih mendalam daripada meluas. Studi kasus lebih menekankan pada analisis lengkap dari sejumlah kejadian atau kondisi dan keterkaitannya. Jadi, studi kasus pada dasarnya merupakan penyelidikan intensif terhadap unit tertentu yang sedang dipertimbangkan. Objek dari metode studi kasus adalah untuk menemukan faktor-faktor yang menjelaskan pola perilaku unit yang diberikan sebagai totalitas terpadu (Kothari, 2004, hal. 113). Penulis mengeksplorasi secara mendalam program, acara, aktivitas, proses, atau satu atau lebih individu (Creswell, 2003, hal.15,). Selanjutnya, analisis data dilakukan melalui deskripsi kasus, tema kasus, serta tema lintas kasus (Creswell, 2007, hal. 78-79). 
Penonton yang datang pada pertunjukan Hellprint 2018 datang dari berbagai tempat yang berjauhan dengan usia dan profesi yang beragam. Penulis tidak memiliki kesempatan untuk mendatangi rumah-rumah mereka, sehingga untuk mendapatkan data yang diharapkan, penulis mendatangi narasumber yang berada di venue untuk diwawancara dan diamati secara langsung. Pada saat melakukan wawancara, penulis dibantu oleh dua orang asisten yang ditugaskan untuk mewawancarai secara langsung.

Penyelenggara memberikan break time kepada penonton yaitu jam 15.00-15.30, dan 17.30-19.30. Saat break time tersebut oleh penonton dipergunakan untuk beristirahat secara berkelompok sambil berbincang, makan, dan minum dengan kelompoknya masing-masing. Setelah dilakukan pengamatan, jumlah kelompok mereka terdiri dari 5 hingga 10 orang yang terdiri dari pria dan wanita. Akan tetapi ada juga kelompok penonton yang melakukan aktivitas tersebut pada saat acara sedang berlangsung, yaitu kelompok yang berada di baris belakang. Dengan kondisi seperti ini, penulis memutuskan untuk mendatangi kelompok-kelompok penonton dan menentukan 6 orang dari mereka secara random untuk dijadikan sebagai narasumber, sementara kelompok penonton yang berhasil diwawancara adalah sebanyak 9 kelompok random. Pembatasan kelompok dilakukan karena penulis tidak mendapatkan informasi baru, yang artinya data sudah jenuh. Dengan demikian jumlah total narasumber yang diwawancara adalah 54 orang. Sebagai pelengkap data, penulis mewawancara pihak penyelenggara dan sponsor secara purposive yaitu Dany Kajul (boss Hellprint Officials) dan Gregorius Prahara Bayu (project officer dari supermusic.id).

Wawancara dilakukan melalui percakapan secara terbuka (open ended) dengan pertanyaan garis besar dan bersifat situasional. Pertanyaan garis besar tersebut terdiri dari dua faktor atau variabel penelitian yaitu: "Apa motivasi Anda menghadiri acara Hellprint United Day VI?" dan "Bagaimana persepsi dan pendapat Anda terhadap penyelenggaraan Hellprint United Day VI?". Sedangkan data untuk faktor inovasi diperoleh melalui pengamatan secara langsung. Wawancara garis besar seperti ini meningkatkan kelengkapan data dan membuat pengumpulan data agak sistematis pada setiap narasumber. Akan tetapi Cohen et. al. (2007, hal. 353) menyatakan bahwa wawancara secara garis besar dianggap memiliki kelemahan. Alasannya adalah bahwa topik-topik penting mungkin secara tidak sengaja dihilangkan. Fleksibilitas pewawancara dalam menggabungkan pertanyaan dan kata-kata dapat menghasilkan respons yang sangat berbeda, sehingga mengurangi komparabilitas tanggapan. Maka, untuk mengantisipasi hal ini penulis melakukan pengawasan dari dekat terhadap asisten pewawancara dan para narasumber. Selain itu dilanjutkan dengan mengajukan pertanyaan investigatif mendalam, termasuk membuang jawaban di luar konteks dan jawaban yang bertele-tele. Selanjutnya penulis melakukan cross check terhadap hasil wawancara dari beberapa narasumber dan melakukan pendalaman saat post event. Untuk mengetahui kuantitas dari masing-masing faktor maka, jumlah pernyataan pada masing-masing jenis faktor (coding) dibagi dengan jumlah sampel dan dikalikan $100 \%$. 


\section{HASIL DAN PEMBAHASAN}

Hasil pengamatan dan wawancara terhadap penyelenggara diperoleh data tentang venue, konsep penyelenggaraan, dan pemasaran acara.

\section{A) Venue}

Hellprint United Day VI diselenggarakan pada tanggal 4 Februari 2018, di Lapangan Pussenif, Jl. Supratman Bandung. Pemilihan lokasi tersebut didasari pada pertimbangan: 1) Untuk meningkatkan citra Hellprint United Day yang identik dengan segmen grass root dan untuk menambah segmentasi penonton terutama kalangan menengah ke atas; 2) Keamanan lebih terjamin karena area pertunjukan berada di kompleks militer; 3) Memiliki sarana parkir yang luas, toilet, kantin, dan sarana ibadah; 4) Area dikelilingi oleh bangunan dan berlantaikan semen sehingga tidak becek saat hujan; 5) Luas lapangan venue berkapasitas 20.000 orang; 6) Memiliki fasilitas food \& beverage indoor kuliner dan mushola yang bisa menampung 1.500 orang.

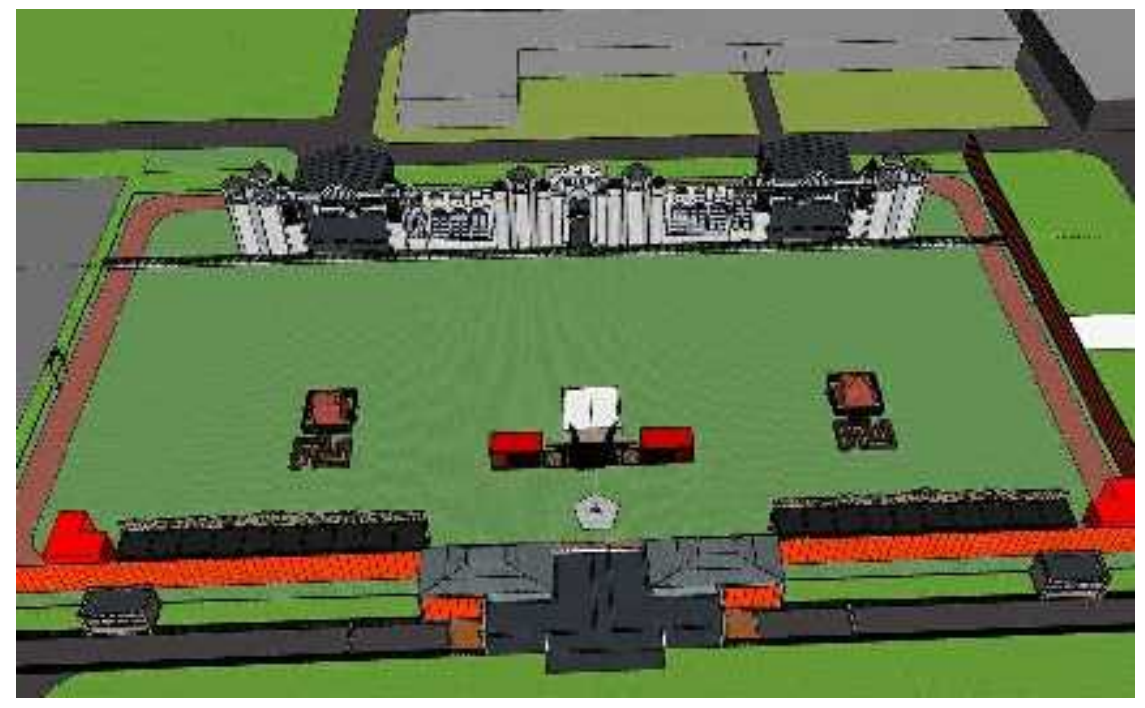

Gambar 1. Layout venue Hellprint 2018

Hellprint 2018/dok. Hellprint Official

B) Konsep penyelenggaraan

Hellprint United Day VI menampilkan 47 band yang diselenggarakan menggunakan konsep festival dengan dua main stage arena dan diatur dengan rundown mengikuti pola rally show.

C) Pemasaran acara

a. Promosi acara dilakukan melalui Instagram @ hellprintofficial dan Facebook Hellprint-United DAY, termasuk mengandalkan word of mouth di antara anggota komunitas metal underground.

b. Penjualan tiket dilakukan secara pre sale dengan harga Rp. 50.000/lembar dengan outlet/ticket box mayoritas di Jawa Barat, dan sisanya di Jakarta, MARDATILLAH - Tangerang, DAHMER - Brebes, GO KILL - Kebumen, INGGIT - 
Yogyakarta, EQUALITY - Grobogan, VYRUS STORE - Gresik, DISHARMONIC Mojokerto.

Hasil pengamatan dan wawancara terhadap penonton diperoleh data tentang karakteristik narasumber, pernyataan mereka tentang motivasi dan persepsi terhadap acara.

a) Karakteristik narasumber berdasarkan kelompok:

\begin{tabular}{|c|c|c|c|c|}
\hline Kelompok & Umur & Tempat tinggal & Informasi event & Keterangan \\
\hline 1 & $18-21$ & Ciamis \& Cimahi & Instagram, Facebook & Rutin hadir \\
\hline 2 & $17-23$ & Pangalengan, Kabupaten Bandung & Instagram, Facebook & Rutin hadir \\
\hline 3 & $14-18$ & Padalarang, Kabupaten Bandung & Instagram, Facebook & Rutin hadir \\
\hline 4 & $17-22$ & Majalaya, Kabupaten Bandung & Instagram, Facebook & Rutin hadir \\
\hline 5 & $19-21$ & Bandung & Instagram dan teman & Rutin hadir \\
\hline 6 & $17-22$ & Jatinangor, Sumedang & Instagram, Facebook & Rutin hadir \\
\hline 7 & $28-32$ & Garut & $\begin{array}{c}\text { Instagram, Facebook, } \\
\text { dan teman }\end{array}$ & Rutin hadir \\
\hline 8 & $27-30$ & Bandung & Instagram, Facebook & Rutin hadir \\
\hline 9 & $22-31$ & Bandung \& Cirebon & $\begin{array}{c}\text { Instagram, Facebook, } \\
\text { dan teman }\end{array}$ & Rutin hadir \\
\hline
\end{tabular}

b) Hasil wawancara.

Wawancara difokuskan terhadap motivasi mereka mendatangi acara dan persepsi mereka saat berada di venue. Hasil wawancara diolah secara line by line dan selanjutnya dilakukan kodifikasi (coding). Pada saat menentukan selective coding penulis tidak mengubah pernyataan (ungkapan/istilah) narasumber menjadi coding yang bersifat general karena masing-masing coding yang diperoleh memiliki makna yang khas. Namun demikian ada pula pernyataan narasumber yang bermakna sama tetapi berbeda istilah.

\section{Motivasi}

Dari hasil olah data terhadap pernyataan 54 narasumber diperoleh 18 coding tentang motivasi mereka menghadiri konser Hellprint 2018. Setiap coding memiliki kuantitas sesuai dengan jumlah coding yang diperoleh dari narasumber dan selanjutnya dinyatakan ke dalam persentase (\%). Selanjutnya data narasumber penonton dianalisis dengan mencari hubungan di antara data tersebut, sehingga diperoleh hasil analisis seperti yang ditabulasikan di bawah ini.

\begin{tabular}{|c|c|c|c|}
\hline No & Kodifikasi & Kuantitas & Remarks \\
\hline 1 & Silaturahmi & $66 \%$ & $\begin{array}{l}\text { Hal ini menunjukkan bahwa narasumber terdiri dari } \\
\text { kelompok-kelompok yang berasal dari satu entitas dan } \\
\text { masing-masing anggota kelompok sudah saling } \\
\text { mengenal dan rutin mendatangi Hellprint United Day. } \\
\text { Dengan demikian Hellprint United Day adalah sebuah } \\
\text { event festival yang difungsikan sebagai tempat } \\
\text { bersosialisasi oleh penonton dan hal ini sama dengan } \\
\text { event festival lainnya. Penonton event festival punya } \\
\text { rasa memiliki terhadap acara karena event seperti ini } \\
\text { mengakomodasikan kebutuhan penonton secara lebih } \\
\text { kontekstual (Philips \& Cogen, 2009), mengeksplorasi } \\
\text { faktor sosial, termasuk mengakomodasikan loyalitas }\end{array}$ \\
\hline
\end{tabular}




\begin{tabular}{|c|c|c|c|}
\hline & & & $\begin{array}{l}\text { penonton (Pitts \& Spencer, 2008) terhadap komunitas } \\
\text { (Burland \& Pitts, 2010). Bagi penonton dengan } \\
\text { motivasi silaturahmi, pengalaman berinteraksi } \\
\text { interpersonal maupun dengan kelompok akan menjadi } \\
\text { pengalaman yang menyenangkan. }\end{array}$ \\
\hline 2 & Hobi & \multirow[t]{3}{*}{$55 \%$} & \multirow[b]{3}{*}{$\begin{array}{l}\text { - Motivasi hobi menunjukkan bahwa narasumber } \\
\text { berpotensi untuk selalu datang karena mereka adalah } \\
\text { penyuka musik. Aktivitas mengapresiasi musik } \\
\text { selama di venue akan menjadi pengalaman yang } \\
\text { dibutuhkan mereka. } \\
\text { - Motivasi hiburan/refreshing akan menjadikan segala } \\
\text { pengalaman yang diperoleh selama di venue sebagai } \\
\text { sebuah hiburan. Sementara motivasi pertemanan } \\
\text { akan menjadikan event sebagai media untuk } \\
\text { berteman dengan sesama penyuka musik. } \\
\text { - Penyelenggara perlu membenamkan penonton yang } \\
\text { seperti ini ke dalam pengalaman dan makna yang } \\
\text { berbeda dengan keseharian mereka (Getz, 2008), } \\
\text { agar mereka sering menghadiri event (Pitts \& } \\
\text { Spencer, 2008). }\end{array}$} \\
\hline 3 & $\begin{array}{l}\text { Hiburan dan } \\
\text { Refreshing }\end{array}$ & & \\
\hline 4 & Pertemanan & & \\
\hline 5 & Persahabatan & \multirow[t]{3}{*}{$44 \%$} & \multirow[b]{3}{*}{$\begin{array}{l}\text { Motivasi untuk menyaksikan dan mendukung band } \\
\text { yang digemari, menjaga persahabatan dengan sesama } \\
\text { penggemar, dan menjadikan Hellprint United Day } \\
\text { sebagai sumber pengetahuan, muncul pada penggemar } \\
\text { musik dan pelaku di bidang industri musik (musisi, } \\
\text { vendor pertunjukan, penyelenggara acara) yang sering } \\
\text { mendatangi event. Walaupun Kruger dan Saayman } \\
\text { (2012) menyatakan motivasi penonton di masing- } \\
\text { masing wilayah atau negara akan berbeda, tetapi } \\
\text { pernyataan narasumber sama dengan dua pernyataan } \\
\text { terdahulu bahwa event akan menjadi tempat pertemuan } \\
\text { yang bermakna antar berbagai ide dan orang (Lobert, } \\
\text { 2012), pengayaan budaya, pendidikan, kebaruan, dan } \\
\text { sosialisasi (Crompton \& McKay, 1997). }\end{array}$} \\
\hline 6 & Fans salah satu band & & \\
\hline 7 & Pengetahuan & & \\
\hline 8 & Fans beberapa band & \multirow[t]{3}{*}{$33 \%$} & \multirow{3}{*}{$\begin{array}{l}\text { Motivasi keempat dari populasi penonton adalah untuk } \\
\text { kesenangan dan kebahagiaan. Mereka menunjukkan } \\
\text { perasaannya dengan ikut menari. Adanya keterlibatan } \\
\text { fisik, hubungan interpersonal atau sosial, dan pribadi } \\
\text { penonton (Getz, 1991) dengan event hingga menjadi } \\
\text { sebuah pengalaman (Pine dan Gilmore, 1999), sangat } \\
\text { dibutuhkan penonton pada motivasi ini. }\end{array}$} \\
\hline 9 & $\begin{array}{l}\text { Kesenangan dan } \\
\text { kebahagiaan }\end{array}$ & & \\
\hline 10 & Menari & & \\
\hline 11 & Kepuasan & \multirow[t]{8}{*}{$11 \%$} & \multirow{8}{*}{$\begin{array}{l}\text { Motivasi kelima dari populasi penonton yang hadir } \\
\text { dapat dibagi dua; } \\
\text { - Motivasi untuk menghadiri event langka dan men- } \\
\text { support acara, menunjukkan bahwa mereka adalah } \\
\text { penggemar musik metal yang logis dan mapan. } \\
\text { - Motivasi untuk kepuasan, nyari jodoh, pelampiasan, } \\
\text { bernyanyi, penasaran, dan foto, menunjukkan bahwa } \\
\text { mereka adalah penonton sensoris yang datang hanya } \\
\text { untuk menikmati suasana di venue. } \\
\text { Bagi penonton yang seperti ini event harus memberikan } \\
\text { pengalaman yang menarik dan tak terlupakan, serta } \\
\text { mampu memberikan kebanggaan. }\end{array}$} \\
\hline 12 & Nyari jodoh & & \\
\hline 13 & Pelampiasan & & \\
\hline 14 & Event langka & & \\
\hline 15 & Bernyanyi & & \\
\hline 16 & Penasaran & & \\
\hline 17 & Support acara & & \\
\hline 18 & Foto & & \\
\hline
\end{tabular}




\section{Persepsi.}

Hasil olah data terhadap pernyataan 54 narasumber diperoleh coding tentang persepsi mereka saat menghadiri konser Hellprint 2018. Setiap coding memiliki kuantitas sesuai dengan jumlah coding yang diperoleh dari narasumber dan selanjutnya dinyatakan ke dalam persentase $(\%)$.

\begin{tabular}{|c|c|c|c|}
\hline No & Kodifikasi & Kuantitas & Remarks \\
\hline 1 & $\begin{array}{l}\text { Desain dan artistik } \\
\text { panggung. }\end{array}$ & $100 \%$ & $\begin{array}{l}\text { Inovasi pada desain dan artistik panggung dipersepsikan } \\
\text { sebagai unsur yang paling menarik perhatian dan disukai } \\
\text { seluruh penonton. Hal ini mengindikasikan keberhasilan } \\
\text { dari inovasi pada faktor tersebut. }\end{array}$ \\
\hline 2 & $\begin{array}{l}\text { Karakteristik } \\
\text { venue. }\end{array}$ & $100 \%$ & $\begin{array}{l}\text { Pemilihan venue dengan karakteristik seperti Lapangan } \\
\text { Pussenif Bandung sangat disukai seluruh narasumber } \\
\text { karena memiliki fasilitas yang dibutuhkan penonton } \\
\text { festival/konser metal. Hal ini mengindikasikan } \\
\text { keberhasilan dari inovasi pada faktor tersebut. }\end{array}$ \\
\hline 3 & Lokasi venue. & $100 \%$ & $\begin{array}{l}\text { Lokasi venue dipersepsikan sebagai lokasi yang ideal } \\
\text { dan sangat disukai seluruh penonton karena aman dan } \\
\text { mudah diakses. Hal ini mengindikasikan keberhasilan } \\
\text { dari inovasi pada faktor tersebut. }\end{array}$ \\
\hline 4 & Kualitas band. & $100 \%$ & $\begin{array}{l}\text { Seluruh band yang tampil dipersepsikan sebagai band } \\
\text { yang berkualitas dan memuaskan penonton. Hal ini } \\
\text { mengindikasikan keberhasilan dari inovasi pada faktor } \\
\text { tersebut. }\end{array}$ \\
\hline 5 & Ticketing. & $100 \%$ & $\begin{array}{l}\text { Pengelolaan tiket dipersepsikan sangat baik oleh seluruh } \\
\text { penonton karena harganya terjangkau, mudah didapat, } \\
\text { dan ada bonus tiket/hadiah. Selain itu manajemen } \\
\text { antrian di pintu masuk sangat baik, nyaman, dan aman. } \\
\text { Hal ini mengindikasikan keberhasilan dari inovasi pada } \\
\text { tata kelola ticketing. }\end{array}$ \\
\hline 6 & Luas venue. & $90 \%$ & $\begin{array}{l}\text { Hal ini menunjukkan bahwa penentuan luas venue } \\
\text { mampu mengakomodasikan keinginan } 90 \% \text { penonton. }\end{array}$ \\
\hline 7 & Genre musik. & $90 \%$ & $\begin{array}{l}\text { Hal ini menunjukkan bahwa genre musik yang } \\
\text { ditampilkan mampu mengakomodasikan keinginan } 90 \% \\
\text { penonton. }\end{array}$ \\
\hline 8 & $\begin{array}{l}\text { Tata kelola } \\
\text { pengamanan. }\end{array}$ & $90 \%$ & $\begin{array}{l}\text { Pengamanan di luar dan di dalam venue dipersepsikan } \\
\text { baik oleh } 90 \% \text { penonton. }\end{array}$ \\
\hline 9 & $\begin{array}{l}\text { Fasilitas penonton: } \\
\text { toilet, musala, } \\
\text { sarana makan \& } \\
\text { minum, booth } \\
\text { merchandise, } \\
\text { booth games, } \\
\text { tempat } \\
\text { bersosialisasi, } \\
\text { ATM, area } \\
\text { istirahat. }\end{array}$ & $90 \%$ & $\begin{array}{l}\text { Inovasi penyelenggara terhadap fasilitas penonton } \\
\text { (hospitality) dipersepsikan baik oleh } 90 \% \text { penonton. }\end{array}$ \\
\hline 10 & $\begin{array}{l}\text { Tata kelola } \\
\text { panggung. }\end{array}$ & $80 \%$ & $\begin{array}{l}\text { Penempatan dua panggung arena yang bersebelahan } \\
\text { dipersepsikan positif oleh } 80 \% \text { penonton dan negatif } \\
\text { oleh } 20 \% \text { penonton. Dengan demikian penyelenggara } \\
\text { harus mempertimbangkan inovasi tata kelola panggung } \\
\text { untuk meminimalisasi persepsi negatif. }\end{array}$ \\
\hline
\end{tabular}




\begin{tabular}{|c|l|c|l|}
\hline 11 & Jumlah band. & $80 \%$ & $\begin{array}{l}\text { Keputusan untuk menampilkan 47 band dalam satu hari } \\
\text { oleh 80\% narasumber dipersepsikan positif dan negatif } \\
\text { oleh 20\% penonton. Dengan demikian penyelenggara } \\
\text { harus mempertimbangkan inovasi jumlah band untuk } \\
\text { meminimalisasi persepsi negatif. }\end{array}$ \\
\hline 12 & Suasana di venue & $80 \%$ & $\begin{array}{l}\text { Suasana yang diciptakan di venue oleh penyelenggara } \\
\text { dipersepsikan positif oleh 80\% penonton, dan negatif } \\
\text { oleh 20\% penonton. Dengan demikian penyelenggara } \\
\text { harus mempertimbangkan inovasi penciptaan suasana di } \\
\text { venue untuk meminimalisasi persepsi negatif. }\end{array}$ \\
\hline 13 & $\begin{array}{l}\text { Audio/Sound } \\
\text { system }\end{array}$ & $60 \%$ & $\begin{array}{l}\text { Kualitas audio/sound system dipersepsikan positif oleh } \\
\text { 60\% penonton dan negatif oleh 40\% penonton. Hal ini } \\
\text { mengindikasikan bahwa inovasi yang terkait dengan } \\
\text { faktor-faktor yang berhubungan dengan audio perlu } \\
\text { dikaji ulang, termasuk akustik di venue itu sendiri. }\end{array}$ \\
\hline
\end{tabular}

\section{Pembahasan}

Hasil analisis menunjukkan bahwa motivasi terbesar penonton adalah silaturahmi, hobi, hiburan/refreshing, dan pertemanan. Hal ini menunjukkan bahwa Hellprint United Day VI di mata penonton masih dianggap sebagai event komunitas, sehingga mayoritas yang datang adalah anggota komunitas dan mereka hadir secara rutin. Anggota komunitas dapat terdiri dari penggemar musik metal, musisi, dan praktisi atau pelaku industri pada musik tersebut.

Pada saat narasumber menyatakan bersosialisasi (silaturahmi, pertemanan, persahabatan) sebagai motivasi, penulis menafsirkan bahwa band yang tampil tidak diperhatikan sepenuhnya. Padahal jumlah band dan genre yang ditampilkan, dipersepsikan positif oleh mayoritas narasumber. Hal ini mengindikasikan adanya kejenuhan narasumber terhadap band yang tampil karena mereka terlalu sering menonton band-band yang tampil pada Hellprint United Day VI. Penonton yang hadir dengan motivasi ini akan memperhatikan berbagai aspek yang terdapat pada event, terutama tata kelola hospitality. Konsep dan desain yang sama pada setiap penyelenggaraan event dipastikan akan membuat mereka jenuh dan dapat mengurangi motivasi kehadiran. Akan tetapi perubahan konsep dan desain tersebut harus berdasarkan pada kebutuhan atau motivasi penonton.

Sedangkan hasil analisis pada persepsi penonton menunjukkan bahwa inovasi yang dilakukan pada beberapa faktor sangat berhasil, terutama pada desain dan artistik panggung (Gambar 2.), pemilihan venue, kualitas band, dan ticketing. Namun demikian, kepuasan di bidang audio masih harus diperbaiki mengingat rendahnya persepsi positif penonton pada bidang ini. Permasalahan pada bidang audio tidak ditimbulkan oleh peralatan audio dan tenaga kerja di bidang tersebut, melainkan oleh aspek lain yang terkait dengan pengelolaan di bidang waktu. Beberapa narasumber menyatakan bahwa penyebab ketidaknyamanan di bidang audio akibat pengaturan rundown acara pada kedua panggung yang berjalan secara bersamaan. Dengan rundown yang seperti ini penonton menjadi bingung pada saat ada dua band idolanya tampil dalam waktu yang sama pada panggung yang berbeda. Jika penulis cermati, permasalahan ketidaknyamanan pada faktor audio akibat band yang tampil terlalu banyak. Dengan kondisi yang seperti ini, 
pembuatan rundown akan mengacu pada banyaknya jumlah band yang ditampilkan dengan alokasi waktu yang terbatas.

Dengan munculnya permasalahan ini, pada penyelenggaraan berikutnya, penyelenggara tidak perlu memaksakan menampilkan banyak band. Panggung yang disediakan cukup satu dan setiap band mendapatkan durasi tampil yang sesuai dengan harapan penonton. Berdasarkan hasil cross check terhadap beberapa persepsi narasumber maka penambahan jumlah band harusnya berhubungan dengan jumlah waktu yang disediakan, bukan dengan jumlah panggung. Namun demikian, ke semuanya itu tergantung dari konsep (event screenplay) atau skenario pengalaman yang akan diberikan kepada penonton. Pembuatan rundown itu sendiri pada ahirnya akan berdasarkan pada event screenplay atau skenario, bukan berdasarkan pada jumlah band yang tampil atau ketersediaan waktu.

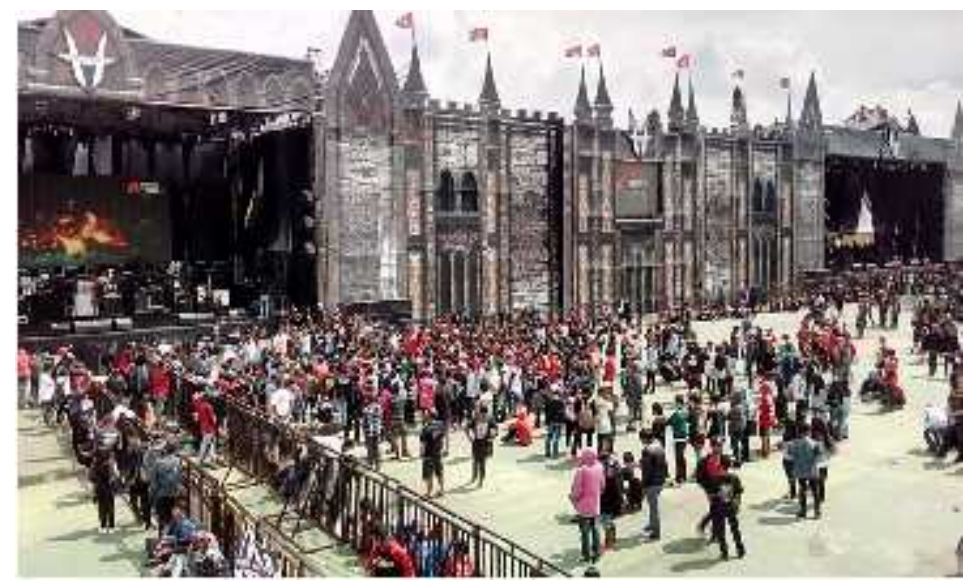

Gambar 2. Inovasi panggung dan suasana penonton di awal pertunjukan Hellprint 2018/Foto dok. Yayat Ahmad Hidayat

Hasil penelitian ini menunjukkan adanya keterhubungan antara inovasi, motivasi, dan persepsi penonton pada event Hellprint United Day VI seperti yang disajikan pada Gambar 3.

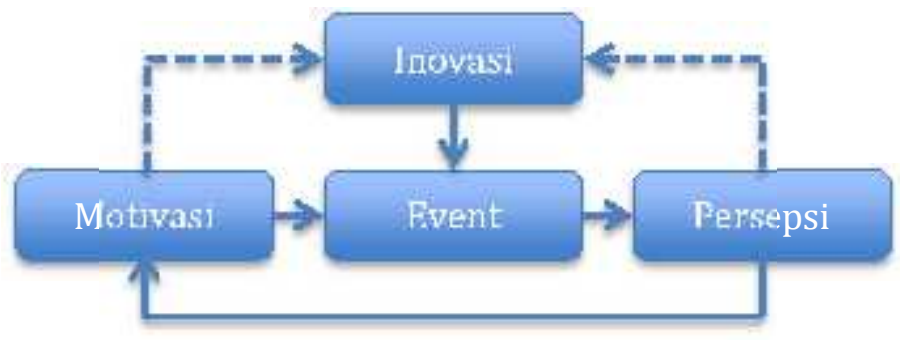

Gambar 3. Hubungan motivasi, persepsi, dan inovasi pada event Hellprint United Day. 
Dengan selesainya penelitian ini, penulis mengharapkan kepada para peneliti mendatang untuk melakukan penelitian lanjutan tentang pengaruh atau korelasi antara persepsi penonton pada Hellprint United Day VI dengan tingkat kehadiran penonton pada Hellprint United Day berikutnya.

\section{KESIMPULAN}

Dari hasil penelitian ini, penulis mendapatkan beberapa temuan dan kesimpulan sebagai berikut:

1. Penonton Hellprint United Day VI mayoritas berasal dari entitas atau komunitas yang sama dan mereka rutin (hobi) menghadiri event Hellprint United Day. Penonton seperti ini motivasi utamanya adalah bersosialisasi (silaturahmi, pertemanan, persahabatan) dan hiburan. Dengan demikian, hospitality dan pengalaman baru akan sangat memengaruhi persepsi mereka terhadap event.

2. Inovasi yang dilakukan penyelenggara terhadap beberapa faktor pendukung (infrastruktur) telah dipersepsikan secara positif dan ini mengindikasikan telah terpenuhinya harapan penonton. Akan tetapi, menampilkan 47 band pada dua panggung dalam satu hari menghasilkan rundown yang tidak tepat dan menimbulkan rendahnya persepsi penonton terhadap kenyamanan audio. Hal ini akan memengaruhi kualitas pengalaman yang mereka dapatkan dan berdampak pada motivasi mereka terhadap penyelenggaraan Hellprint United Day berikutnya.

3. Setiap penyelenggaraan Hellprint United Day selalu menuntut konsep baru dari penyelenggara dan hal ini dapat diperoleh dengan inovasi yang berdasarkan pada motivasi dan persepsi penonton pada penyelenggaraan sebelumnya.

\section{KEPUSTAKAAN}

Bennett, A. 2011. "The post-subcultural turn: some reflections 10 years on", Journal of Youth Studies, Vol. 14, No. 5, 493-506.

Bernstein, A. Douglas; Penner, A. Louis; Stewart, Clarke Alison; Roy, J. Edward. 2008. Psychology, $8^{\text {th }}$ Edition, Houghton Mifflin Company, 222 Berkeley Street, Boston, MA 02116-3764.

Bowdin, Glenn A.J. 2006. Identifying and analysing existing research undertaken in the events industry, UK Centre for Events Management, Leeds Metropolitan University.

Bowdin, Glenn A.J.; Allen, Johnny; O’Toole, William; Harris, Robert; McDonnell, Ian, 2006. Event Management, $2^{\text {nd }}$ Edition. University of Technology, Sydney, Australia Butterworth-Heinemann is an imprint of Elsevier Linacre House, Jordan Hill, Oxford OX2 8DP, 30 Corporate Drive, Suite 400, Burlington, MA 01803.

Burland, K., \& Pitts, S. E. 2010. "Understanding jazz audiences: Listening and learning at the Edinburgh jazz and blues festival". Journal of New Music Research, 39(2), $125-134$.

. 2016. Coughing and clapping: Investigating audience experience. Routledge, 2 Park Square, Milton Park, Abingdon, Oxon OX14 4RN, 711 Third Avenue, New York, NY10017, USA. 
Cohen, Louis; Manion, Lawrence; Morrison, Keith. 2007. Research Method in Education, Sixth Edition. Taylor \& Francis Group, Routledge 2 Park Square, Milton Park, Abingdon, Oxon OX14 4RN.

Cope, L. Andrew. 2010. Black Sabbath and the Rise of Heavy Metal Music, Published by Ashgate Publishing Limited Ashgate, Wey Court East, Union Road, Farnham, Surrey, GU97PT, England.

Creswell, J. W. 2007. Qualitative inquiry and research design: Choosing among five traditions, $2^{\text {nd }}$ ed. Thousand Oaks, CA: SAGE Publication.

. 2003. Research design: Qualitative, quantitative and mixed methods approaches, $2^{\text {nd }}$ ed. Thousand Oaks, CA: SAGE Publications.

Crompton, John L. \& McKay, Stacey L. 1997. "Motives of Visitors Attending Festival Events", Annals of Tourism Research, Vol. 24, No. 2, pp. 425439, 199701997 Elsevier Science Ltd Printed in Great Britain.

Forney, Kristine \& Machlis, Joseph. 2011. The Enjoyment of Music An Introduction to Perceptive Listening, W. W. Norton \& Company, Inc., 500 Fifth Avenue, New York, NY 10110.

Getz, D. 1991. "Festivals, Special Events and Tourism". New York: Van Nostrand Reinhold. 115 Fifth Avenue, New York, NY 10003, 1991, 374 pages. Journal of Travel research, Sagepub, ISSN: 0047-2875, Online ISSN: 1552-6763. . 2007. Event Studies: Theory, Research and Policy for Planned Events, Taylor \& Francis Group, Routledge 2 Park Square, Milton Park, Abingdon, Oxon OX14 $4 \mathrm{RN}$.

. 2005. Event Management and Event Tourism, New York: Cognizant, second revised edition. Taylor \& Francis Group, Routledge 2 Park Square, Milton Park, Abingdon, Oxon OX14 4RN. . 2008. "Event Studies", Oxford: Elsevier. Global Journal of Human Social Science, Volume 11 Issue 10 Version 1.0, December 2011 Type: Double Blind Peer Reviewed International Research Journal Publisher: Global Journals Inc. (USA), Online ISSN: 2249-460x \& Print ISSN: 0975-587X.

Glaser, B. G. \& Strauss, A. L. 1967. The discovery of grounded theory: Strategies for qualitative research. Piscataway, New Jersey: Transaction.

Griffiths, N. K. 2010. "Posh music should equal posh dress: An investigation into the concert dress and physical appearance of female soloists". Psychology of Music, 38(2), 159-177. doi: 10.1177/0305735608100372.

Halsey, Troy. 2010. Freelancer's Guide to Corporate Event Design. Published by Elsevier Inc. All rights reserved, Focal Press, 30 Corporate Drive, Suite 400, Burlington, MA 01803, USA.

Heckhausen, Jutta \& Heckhausen, Heinz. 2018. Motivation and Action, $3^{\text {rd }}$ Edition. Springer International Publishing AG, part of Springer Nature, Gewerbestrasse 11, 6330 Cham, Switzerland.

Heding, Tilde; F. Knudtzen, Charlotte; Bjerre, Mogens. 2009. Brand Management Research, theory and practice. Routledge 2 Park Square, Milton Park, Abingdon, Oxon OX14 4RN.

Holbrook, M. B. 1995. Consumer research: Introspective essays of the study of consumption. Thousand Oaks, CA: Sage Publications.

Kothari, C.R. 2004. Research Methodology, Methods and Techniques. New Agea International (P) Limited, Publishers 4835/24, Ansari Road, Daryaganj, New Delhi - 110002 (www.newagepublishers.com) 
Krahé, C.; Hahn, U., \& Whitney, K. 2015. "Is seeing (musical) believing? The eye versus the ear in emotional responses to music". Psychology of Music, 43(1), 140-148. doi: $10.1177 / 0305735613498920$.

Kruger, M. \& Saayman, M. 2012. "Listen to your heart: motives for attending Roxette live". Journal of Convention \& Event Tourism, 13(3): 181-202.

Lamont, A. 2012. "Emotion, engagement and meaning in strong experiences of music performance", Psychology of Music, 40 (5), 574-594 doi: $10.1177 / 0305735612448510$.

Leedy, P. \& Ormrod, J. 2001. Practical research: Planning and design, $7^{\text {th }}$ ed. Upper Saddle River, NJ: Merrill Prentice Hall. Thousand Oaks: SAGE Publications.

Lobert, A. 2012. "Fandom as a religious form: On the reception of pop music by cliff richard fans in liverpool". Popular Music, 31(1), 125-141. doi: 10.1017/S0261143011000493.

Manners, B. 2012. "The critical succes factors for managing the visitor experience at a major musical event". (Disertasi) Potchefstroom: North-West University, Potchefstroom Campus.

Phillips, W., Cogan, B. 2009. Encyclopedia of Heavy Metal Music. Greenwood Press, Westport, Connecticut, London.

Pitts, S. E., \& Spencer, C. P. 2008. "Loyalty and longevity in audience listening: Investigating experiences of attendance at a chamber music festival". Music and Letters, 89(2), 227-238.

Robinson, Howard. 2013. Perception. Routledge 29 West 35th Street, New York, NY 10001.

Styles, A. Elizabeth. 2005. Attention, Perception and Memory, An integrated introduction. Psychology Press 27 Church Road, Hove, East Sussex, BN3 2FA.

Weinstein, D. 2000. Heavy metal: The music and its culture. Da Capo Press.

Wrathall, J., \& Gee, A. 2011. Event Management: Theory and Practice, 1-2.

Pine, J. \& Gilmore, J.H. 1998. "Welcome to the experience economy", Harvard Business Review 98407, 97-105.

Sumber internet:

www.dictionary.com

www.dictionary.camridge.org

www.kamusbahasaindonesia.org

www.en.oxforddictionaries.com

https://globaljournals.org/journals/human-social-science-journal

https://study.com/academy/lesson/what-is-perception-in-psychology-definition-theoryquiz.html

Sumber informasi tambahan:

- Hellprint Official

- Supermusic.ID 